This Health Hazard Evaluation (HHE) report and any recommendations made herein are for the specific facility evaluated and may not be universally applicable. Any recommendations made are not to be considered as final statements of NIOSH policy or of any agency or individual involved.

HETA 94-0023-2473

NOVEMBER 1994

VETERANS ADMINISTRATION WHITE RIVER JUNCTION, VERMONT
NIOSH INVESTIGATORS: EDWARD A. KAISER, Ph.D. DAVID C. SYLVAIN, M.S., CIH

\title{
I. SUMMARY
}

On September 29, 1993, the National Institute for Occupational Safety and Health (NIOSH) received a request for a Health Hazard Evaluation (HHE) from management at the Veterans Administration Medical and Research Center, White River Junction, Vermont. The request was prompted by employee complaints of fatigue, allergy symptoms, and eye, nose and throat irritation. The request expressed concern about the use of anticorrosion chemicals in boilers which provide steam humidification to occupied areas.

On November 30 and December 1, 1993, NIOSH investigators conducted an HHE at the William A. Yasinski Research and Education Building. Twelve general area air samples were obtained for morpholine and cyclohexylamine, the two anticorrosion chemicals. Three surface wipe samples for morpholine and cyclohexylamine were taken in research laboratories where an oily film was noted. A sheet of plastic, approximately one square foot in area, which had been hanging in a research laboratory for several months, was similarly analyzed for the presence of these compounds. Two bulk samples of steam condensate were analyzed for morpholine and cyclohexylamine. On February 17, 1994, similar air sampling for morpholine and cyclohexylamine was conducted, plus area air sampling for formaldehyde.

Morpholine and cyclohexylamine were not detected in either the air or wipe samples at concentrations which exceeded minimum detectable concentrations of 0.002 parts per million (ppm), and $0.005 \mathrm{ppm}$ respectively. These compounds were, however, detected on the plastic sheet and in the steam condensate samples. Very low levels $(<0.01 \mathrm{ppm})$ of formaldehyde were detected in the area air samples from the research laboratories.

The environmental sampling results indicate that employees are not exposed to airborne morpholine or cyclohexylamine at concentrations above the minimum detectable concentrations for these compounds. Formaldehyde concentrations were at or below what is generally considered "background." Recommenda-tions to address workers' safety and health concerns, including discontinuing direct injection of boiler condensate for humidification, are included in Section VIII of this report.

KEYWORDS: SIC 8733 (non-commercial research organizations), formaldehyde, cyclohexylamine, morpholine, steam humidification, boiler water treatment. 
Page 2 - Health Hazard Report No. 94-0023

\section{INTRODUCTION}

On September 29, 1993, the National Institute for Occupational Safety and Health (NIOSH) received a request to conduct a Health Hazard Evaluation (HHE) at the William A. Yasinski Research and Education Building (Building 44). The request indicated that employees were experiencing eye, nose and throat irritation, allergy symptoms, and fatigue.

On November 30 and December 1, 1993, NIOSH investigators conducted an environmental evaluation at Building 44. Background information on the use and operation of this building was obtained, and environmental monitoring for morpholine and cyclohexylamine was conducted. Additional monitoring for morpholine and cyclohexylamine was conducted on February 17, 1994, in conjunction with area air sampling for formaldehyde.

\section{BACKGROUND}

Building 44, the William A. Yasinski Research and Education Building, was completed in January 1992, and was occupied in March 1992. The building has three floors (ground, first, and second floors) encompassing approximately 40,000 square feet, and is one of a number of buildings comprising the VA complex at White River Junction. The ground level is occupied by offices and lecture halls; the first floor houses animal research laboratories, and the second floor is occupied by researchers. Carpeting is present in offices on the ground floor and in the foyers on all floors. Floors in laboratories and corridors are covered with linoleum.

During the summer of 1992, employees on the ground floor reported experiencing eye irritation and drowsiness. Reports of employee discomfort had not been received prior to moving into the research building, nor have reports been received from occupants of other VA buildings. A review of air sampling performed by VA staff indicated that formaldehyde concentrations exceeded 0.1 parts per million (ppm) on several dates in July 1992, in several different areas of Building 44, but primarily on the ground floor. Repeat formaldehyde sampling later that summer found concentrations to be approximately onetenth of the previous readings. During the winter months (1992), occupants on other floors of Building 44 reported experiencing eye and throat irritation, nasal congestion, headaches, and increased fatigue. Air sampling in March 1993 indicated concentrations of $0.2 \mathrm{ppm}$ formaldehyde in room G-107. Two other repeat samples found $<0.04 \mathrm{ppm}$ in this room. Air sampling for diethylaminoethanol in April 1993 found $<0.01 \mathrm{ppm}$ in three rooms on the ground level.

Four buildings within the VA complex are heated with steam generated by three oil-fired boilers. The boilers are located in a separate building within the complex. In addition to providing heat, steam from the boilers is used in the research building for autoclaves, glass 


\section{Page 3 - Health Hazard Report No. 94-0023}

washers, and humidification. VA records indicate that approximately 160,000 gallons of water per year are used by the boilers to generate steam. Make-up water is treated with an anticorrosion agent which neutralizes carbonic acid in the boilers and steam system. The anticorrosion agent (presently a mixture of morpholine and cyclohexylamine) is added manually each day to a drum which is topped-off with water, and pumped continuously into the deaerator tank, where excess oxygen is removed from boiler make-up water. The amount of additive needed each day is estimated by an operator based upon the $\mathrm{pH}$ of return condensate. Prior to November 1992, the deaerator was inoperative, which resulted in the use of a larger volume of anticorrosion treatment chemicals. At that time, diethanolamine (DEAE) was used as the anticorrosion agent, rather than the present mixture of morpholine and cyclohexylamine.

Each floor of the research building is served by one of three air handling units (AHUs) located in the penthouse. Reportedly, the AHU serving the ground floor provides approximately $40 \%$ outside air. The AHUs serving the other floors provide $100 \%$ outside air. Of the 28,000 cubic feet per minute (cfm) provided to the building, 23,000 cfm is exhausted through laboratory fume exhaust hoods. Chilled water is supplied by chillers located in the penthouse. Floors one and two are humidified from September to June; the ground floor has no humidification capabilities. Humidification is provided by directly injecting boiler steam into the ventilation supply air ductwork serving each of the humidified floors. (Note: only the first floor was being humidified at the time of the NIOSH evaluation.) Relative humidity on humidified floors is monitored by sensors located in AHU ventilation exhaust ductwork. The research building is air-conditioned and dehumidified during the summer.

In addition to reports of employee discomfort, an oily film appeared on plastic and metal surfaces, painted metal surfaces near several supply air diffusers became pitted with rust spots, and heat coils in the AHUs serving humidified floors developed "pin holes." In July 1993, the VA changed from an anticorrosion agent containing DEAE to one with morpholine and cyclohexylamine in an attempt to eliminate employee health concerns. 
Page 4 - Health Hazard Report No. 94-0023

\section{EVALUATION DESIGN AND METHODS}

On November 30 and December 1, 1993, NIOSH investigators conducted environmental sampling on the three floors of the William A. Yasinski Research and Education Building. Twelve area air samples were collected to evaluate employee exposures to morpholine and cyclohexylamine. Sampling was conducted by placing a battery-powered sampling pump in each area to be sampled, drawing air at a nominal flow rate of 100 cubic centimeters per minute through glass tubes containing beds of XAD-2 sorbent coated with the reagent, naphthylisothiocyanate (NITC). Morpholine and cyclohexylamine react with NITC to form thioureas, which can be measured by high performance liquid chromatography (HPLC). Sampling pumps were set at flow rates specified for collecting these compounds, and were calibrated before and after sampling to ensure that the desired flow rates were maintained throughout the sampling period. The minimum detectable and quantifiable concentrations (MDC and MQC) based upon an average sample volume of 33.3 liters, are given below in parts per million:

$\begin{array}{ccccc}\underline{\text { Analyte }} & \begin{array}{c}\text { LOD } \\ (\mu \mathrm{g} / \mathrm{sample})\end{array} & \begin{array}{c}\mathrm{LOQ} \\ (\mu \mathrm{g} / \mathrm{sample})\end{array} & \begin{array}{c}\mathrm{MDC} \\ (\mathrm{ppm})\end{array} & \begin{array}{c}\mathrm{MQC} \\ (\mathrm{ppm})\end{array} \\ \begin{array}{l}\text { Morpholine } \\ \text { Cyclohexylamine }\end{array} & 0.2 & 0.56 & 0.002 & 0.004 \\ \text { LOD }=\text { analytical limit of detection } & 2.7 & 0.005 & 0.016 \\ \text { LOQ }=\text { analytical limit of quantitation } & & & \\ \text { MDC }=\text { minimum detectable concentration } & & & \\ \text { MQC }=\text { minimum quantifiable concentration } & & & \end{array}$

Three surface wipe samples were collected using 4" x 4" commercial non-sterile gauze pads moistened with ethanol. Wipe samples were obtained from painted metal surfaces where an oily film was visible. Wipe samples were collected by donning disposable gloves, wiping an area measuring approxi-mately one square foot, and placing the folded gauze in a sealable vial. To reduce possible cross-contamination, the disposable gloves were changed after each sample was collected. Care was taken to use the same technique for each sample. In addition, a sheet of plastic wrap, approximately one square foot in area, which had been hanging in a laboratory since September 1993 was placed in a vial for analysis. Final solutions of these samples were prepared and analyzed by HPLC. The analytical limits of detection and quantitation for these samples were higher than for the air samples because of dilution. The limits of detection and quantitation were $1 \mu \mathrm{g}$ and 4 $\mu \mathrm{g}$ respectively for morpholine; and $3.0 \mu \mathrm{g}$ and $12 \mu \mathrm{g}$ respectively for cyclohexylamine.

Two bulk samples of steam condensate were obtained from research building supply and return steam lines to determine the concentration of morpholine and cyclohexylamine in the boiler system. The limits of detection and quantitation for the bulk samples were 0.4 $\mu \mathrm{g} / \mathrm{ml}$ and $1.1 \mu \mathrm{g} / \mathrm{ml}$ respectively for morpholine; and $1.4 \mu \mathrm{g} / \mathrm{ml}$ and $4.4 \mu \mathrm{g} / \mathrm{ml}$ respectively for cyclohexylamine. 


\section{Page 5 - Health Hazard Report No. 94-0023}

Formaldehyde sampling conducted by the VA in 1992 and 1993 found concentrations ranging from none detected to $0.6 \mathrm{ppm}$. These results suggested that formaldehyde could be contributing to eye and upper respiratory tract irritation reported by building occupants. On February 17, 1994, the NIOSH investigators returned to conduct area air sampling for formaldehyde. Air sampling for formaldehyde was conducted according to NIOSH Method 3500. ${ }^{(1)}$ Each sample was obtained by drawing air through a midget impinger containing $20 \mathrm{ml}$ of $1 \%$ sodium bisulfite solution. After sampling, the solution from each impinger was transferred to a separate low-density polyethylene bottle for shipment. Field blanks were processed similarly. Samples were analyzed for formaldehyde by visible absorption spectrometry. In addition, sampling for morpholine and cyclohexylamine was repeated in the locations where samples were obtained during the previous visit. This sampling was repeated in order to obtain additional data. Sampling methods were the same as described earlier. The minimum detectable and quantifiable concentrations (MDC and MQC) based upon an average sample volume of 90.9 liters, are given in the table below. The minimum concentrations which could be detected and quantified, based upon an average sample volume of 148 liters, are given below in parts per million:

\begin{tabular}{|c|c|c|c|c|}
\hline Analyte & $\begin{array}{c}\text { LOD } \\
(\mu \mathrm{g} / \mathrm{sample})\end{array}$ & $\begin{array}{c}\text { LOQ } \\
(\mu \mathrm{g} / \mathrm{sample})\end{array}$ & $\begin{array}{l}\text { MDC } \\
(\mathrm{ppm}) \\
\end{array}$ & $\begin{array}{l}\text { MQC } \\
\text { (ppm) }\end{array}$ \\
\hline Formaldehyde & 0.3 & 0.89 & 0.002 & 0.0049 \\
\hline Morpholine & 0.2 & 0.56 & 0.0006 & 0.002 \\
\hline Cyclohexylamine & 0.7 & 2.2 & 0.002 & 0.006 \\
\hline
\end{tabular}

\section{EVALUATION CRITERIA}

As a guide to the evaluation of the hazards posed by workplace exposures, NIOSH field staff employ environmental evaluation criteria for assessment of a number of chemical and physical agents. These criteria are intended to suggest levels of exposure to which most workers may be exposed up to 10 hours per day, 40 hours per week for a working lifetime without experiencing adverse health effects. It is important to note that not all workers will be protected from adverse health effects if their exposures are maintained below these levels. A small percentage may experience adverse health effects because of individual susceptibility, a pre-existing medical condition, and/or a hypersensitivity (allergy).

Some hazardous substances may act in combination with other workplace exposures, the general environment, or with medications or personal habits of the worker to produce health effects even if the occupational exposures are controlled at the level set by the evaluation criterion. These combined effects are often not considered in the evaluation criteria. Also, some substances are absorbed by direct contact with the skin and mucous membranes, and thus potentially increase the overall exposure. Finally, evaluation criteria may change over the years as new information on the toxic effects of an agent become available. 
The primary sources of environmental evaluation criteria for the workplace are: (1) NIOSH Criteria Documents and Recommended Exposure Limits (RELs), (2) the American Conference of Governmental Industrial Hygienists' (ACGIH) Threshold Limit Values (TLV's), ${ }^{(2)}$ and (3) the U.S. Department of Labor (OSHA) occupational health standards. ${ }^{(3)}$ Often, the NIOSH recommendations and ACGIH TLV's are lower than the corresponding OSHA standards. Both NIOSH recommendations and ACGIH TLV's usually are based on more recent information than are the OSHA standards. The OSHA standards also may be required to take into account the feasibility of controlling exposures in various industries where the agents are used; the NIOSH-recommended standards, by contrast, are based primarily on concerns relating to the prevention of occupational disease. In evaluating the exposure levels and the recommendations for reducing these levels found in this report, it should be noted that industry is legally required to meet only those levels specified by an OSHA standard.

A time-weighted average (TWA) exposure refers to the average airborne concentration of a substance during a normal 8-10 hour workday. Some substances have recommended short-term exposure limits (STELs) or ceiling values which are intended to supplement the TWA where there are recognized toxic effects from high short-term exposures.

\section{$\underline{\text { Morpholine }}^{(4)}$}

Morpholine is a colorless, flammable liquid. Above $23^{\circ} \mathrm{F}$, morpholine has a weak ammonia or fishy odor. Morpholine is used in the manufacture of rubber accelerators, waxes, and optical brightening agents for bleaches and detergents. ${ }^{6,7}$ It is also used to inhibit corrosion in steam boiler systems. ${ }^{6}$ Morpholine is a primary skin irritant which can cause a hypersensitive response. Eyes, skin, and mucous membranes are targets for irritation upon exposure to morpholine vapor. ${ }^{6,8}$ Instances of skin and respiratory tract irritation have been observed in industry, but no chronic effects have been reported. ${ }^{9}$ Workers exposed for many hours to low concentrations of morpholine, and its N-ethyl and $\mathrm{N}$-methyl derivatives experienced transient corneal edema and foggy vision with halos around lights. These symptoms were reported to occur after leaving work and disappeared in less than 24 hours following presumed exposure. ${ }^{10}$ A significant increase in the incidence of liver tumors was noted in rats which were fed 10 grams of morpholine $/ \mathrm{kg}$ in conjunction with $0.2 \%$ sodium nitrite in drinking water. ${ }^{11}$ The NIOSH REL is $20 \mathrm{ppm}$, TWA exposure; and 30 ppm STEL. The NIOSH REL lists a SKIN notation, indicating that morpholine is absorbed through skin and mucous membranes. The ACGIH TLV for morpholine exposure is $20 \mathrm{ppm}$. This limit has been established to prevent eye and respiratory tract irritation; and adverse systemic effects. ${ }^{2}$

The current OSHA Permissible Exposure Limit (PEL) for morpholine is 20 ppm, TWA exposure. In 1989, OSHA had instituted a STEL of $30 \mathrm{ppm}$ in addition to the TWA under the Air Contaminants Standard. In July 1992, the 11th Circuit Court of Appeals vacated this standard. OSHA is currently enforcing the $20 \mathrm{ppm}$ TWA standard; however, some states operating their own OSHA approved job safety and health programs will continue to 
enforce the $30 \mathrm{ppm}$ STEL in addition to the $20 \mathrm{ppm}$ TWA. OSHA continues to encourage employers to follow the STEL, as well as the TWA.

\section{Cyclohexylamine $^{(5)}$}

Cyclohexylamine is a toxic liquid with a strong, fishy, amine odor. It is intensely irritating to the skin and is regarded as having moderate sensitizing potential. ${ }^{6}$ Dermal exposure of guinea pigs to cyclohexylamine for 24-hours had a 50\% death rate at a dose level between 1 and 5 milliliters per kilogram $(\mathrm{ml} / \mathrm{kg}){ }^{12}$ Other animals exposed to airborne concentrations of $150 \mathrm{ppm}$ cyclohexylamine for 70 hours resulted in a few deaths. ${ }^{13}$ The same study described three nonfatal human exposures to cyclohexylamine vapor which revealed a strong irritant property with nausea and vomiting in these individuals. The authors also reported that no symptoms of any kind occurred in workers exposed to 4-10 ppm cyclohexylamine. In 1989, nurses at a Portland, Oregon, hospital had similar complaints of eye and upper respiratory tract irritation after the introduction of cyclohexylamine and morpholine into boiler water used to humidify the nursery and the newborn intensive care unit. ${ }^{14}$ The airborne concentration of cyclohexylamine and morpholine at the time of the symptoms was unknown. Also in 1989, workers in an electronics manufacturing plant developed symptoms consistent with acute toxic effects of diethylaminoethanol and cyclohexylamine after being exposed to humidification steam containing these compounds. ${ }^{15}$ Sixty-five employees from throughout the plant developed symptoms which included nausea, dizziness, vomiting, and eye, nose, and throat irritation. The NIOSH REL and the ACGIH TLV for cyclohexylamine exposure are $10 \mathrm{ppm}$ as a TWA. $^{2}$

Currently, there is no OSHA (PEL) for cyclohexylamine; however, OSHA had established a PEL-TWA of $10 \mathrm{ppm}$ in 1989 under the Air Contaminants Standard. In July 1992, the 11th Circuit Court of Appeals vacated this standard, deleting the PEL; however, some states operating their own OSHA approved job safety and health programs will continue to enforce the PEL-TWA of $10 \mathrm{ppm}$. OSHA continues to encourage employers to follow the 10 ppm limit.

\section{Formaldehyde}

Formaldehyde is a colorless gas with a strong odor. Exposure can occur from both inhalation and skin absorption. The acute effects associated with formaldehyde are irritation of the eyes and respiratory tract and sensitization of the skin. The first symptoms associated with formaldehyde exposure, at concentrations of 0.1 to 5 parts per million (ppm), are burning of the eyes, tearing, and general irritation of the upper-respiratory tract. There is variation among individuals regarding sensitivity toward formaldehyde, and specifically in terms of an individual's tolerance and susceptibility to acute exposures of the compound. ${ }^{16}$ In two separate studies, formaldehyde has induced a rare form of nasal cancer in rodents. Formaldehyde exposure has been identified as a possible causative factor in cancer of the upper-respiratory tract in a proportionate mortality study of workers in the garment industry. ${ }^{17}$ Statistically significant excesses in mortality from cancers of the 
Page 8 - Health Hazard Report No. 94-0023

buccal cavity and connective tissue were found among exposed workers. ${ }^{17,18}$ NIOSH has identified formaldehyde as a suspected human carcinogen and recommended that exposures be reduced to the lowest feasible concentra-tion. The OSHA PEL is $0.75 \mathrm{ppm}$ as an 8-hour TWA and 2 ppm as a STEL. ${ }^{3}$ ACGIH has designated formaldehyde to be a suspected human carcinogen and, therefore, recommends that worker exposure by all routes should be carefully controlled to levels "as low as reasonably achievable" below the TLV. $^{2}$ The current ACGIH TLV is $0.3 \mathrm{ppm}$ as a ceiling limit.

VI. RESULTS

Morpholine and Cyclohexylamine

Air sampling for morpholine and cyclohexylamine detected neither compound in the area air samples that were obtained on the three floors of the research building. Neither compound was detected on any of the wipe samples which were taken in rooms 2-117, 2123, and 2-138. These amines were found, however, on the sheet of plastic wrap which had been hanging in room 2-136 since September 1993. Analysis of the plastic sheet, which was approximately $1 \mathrm{ft}^{2}$ in area, detected $2.1 \mu \mathrm{g}$ of morpholine and $6.2 \mu \mathrm{g}$ of cyclohexylamine. These quantities are between the LOD and LOQ of the two analytes.

Analysis of condensate obtained from supply and return steam lines serving the research building revealed $5.20 \mathrm{ppm}$ morpholine in condensate from the supply side, and $3.98 \mathrm{ppm}$ morpholine in return condensate. No cyclohexylamine was detected in supply condensate, and $1.5 \mathrm{ppm}$ was detected in return condensate. The limits of detection and quantitation were $0.4 \mu \mathrm{g} / \mathrm{ml}$ and $1.1 \mu \mathrm{g} / \mathrm{ml}$ respectively for morpholine; and $1.4 \mu \mathrm{g} / \mathrm{ml}$ and $4.4 \mu \mathrm{g} / \mathrm{ml}$ respectively for cyclohexylamine.

\section{Formaldehyde}

Low concentrations of formaldehyde were detected in each of the air samples. Although no source of airborne formaldehyde was observed during the evaluation, it should be noted that low concentrations of formaldehyde are often present in indoor environments. Ambient (outdoor) levels of formaldehyde have been reported to range from $\leq 0.005 \mathrm{ppm}$ to $0.06 \mathrm{ppm}$ near industrial areas, or in areas of heavy smog. ${ }^{19}$ Air sampling results are presented below.

Analytical Results - Formaldehyde

\begin{tabular}{|cccc|}
\hline Location & $\begin{array}{c}\text { Sampling Period } \\
\text { (a.m. - p.m.) }\end{array}$ & $\begin{array}{c}\text { Sample Volume } \\
\text { (liters) }\end{array}$ & $\begin{array}{c}\text { Concentration } \\
\text { (ppm) }\end{array}$ \\
\hline $2-123$ & $8: 22-4: 27$ & 147 & $(0.004)$ \\
$1-126$ & $8: 27-4: 15$ & 146 & 0.006 \\
$1-114$ & $8: 30-4: 24$ & 148 & 0.0051 \\
G-107 & $8: 32-4: 16$ & 139 & 0.0064 \\
\hline
\end{tabular}

( ) Concentration between MDC and MQC 
Page 9 - Health Hazard Report No. 94-0023

\section{DISCUSSION}

Air samples did not indicate excessive exposure to airborne concentrations of cyclohexylamine or morpholine on the days of the NIOSH evaluation. However, these compounds were detected on a sheet of plastic present in one of the research laboratories for several months. This indicates that they were previously present in the air of occupied spaces, but their respective airborne concentrations are not known.

Analysis of air samples obtained on February 17, 1994, revealed airborne formaldehyde levels which were well-below $0.1 \mathrm{ppm}$, which is the lowest level generally recognized to cause eye and upper-respiratory irritation.

\section{CONCLUSION AND RECOMMENDATION}

Even though this evaluation did not detect airborne concentrations of cyclohexylamine and morpholine in building 44, the use of amine-treated boiler steam for humidification is not recommended. Amine compounds have the potential to produce eye and respiratory tract irritation, and should not be introduced into the building via the air handling system. A more appropriate humidification technique is to use steam generated at the air handling units which can be injected directly into the supply air.

\section{REFERENCES}

1. National Institute for Occupational Safety and Health. NIOSH manual of analytical methods, Volume 1, Third Edition. Cincinnati, Ohio. DHHS (NIOSH) Publication No. 84-100, Jan. 1984.

2. American Conference of Governmental Industrial Hygienists. Threshold limit values for chemical substances and physical agents in the workroom environment and biological exposure indices with intended changes for 1994 - 1995. Cincinnati, Ohio. American Conference of Governmental Industrial Hygienists, (ACGIH), 1994.

3. Occupational Safety and Health Administration. OSHA safety and health standards. 29 CFR 1910.1000. Occupational Safety and Health Administration, revised 1993.

4. Occupational Diseases: A Guide to Their Recognition. National Institute for Occupational Safety and Health. (NIOSH). (DHEW Publication No. 77-181. NIOSH).

5. Encyclopedia of Occupational Safety and Health. Geneva, Switzerland: International Labor Organization, 1983.

6. National Institute for Occupational Safety and Health. NIOSH/OSHA Occupational Health Guidelines for Chemical Hazards. Cincinnati, Ohio: National Institute for Occupational Safety and Health, 1981. (DHHS (NIOSH) publication no. 81-123). 
Page 10 - Health Hazard Report No. 94-0023

7. Documentation of the Threshold Limit Values and Biological Exposure Indices, 5th ed, Supplemental Documentation 1990. Cincinnati, Ohio. American Conference of Governmental Industrial Hygienists (ACGIH), 1990.

8. Proctor NH, Hughes JP, Fischman ML: Chemical Hazards of the Work Place, 2nd ed. J. B. Lippincott Co., Philadelphia 1988.

9. Reinhardt CT, Brittelli MR: Heterocyclic and miscellaneous nitrogen compounds. In Clayton GD, Clayton FE (eds): Patty's Industrial Hygiene and Toxicology, 3rd ed, rev, Vol 2A, Toxicology, pp 2693-2696. New York, Wiley Interscience, 1981.

10. Grant WM: Toxicology of the Eye, 2nd ed. Springfield, IL, Charles C. Thomas, 1974.

11. Mirvish SS et al: Liver and forestomach tumors and other forestomach lesions in rats treated with morpholine and sodium nitrate, with and without sodium ascorbate. J Natl Cancer Inst 71:81-84, 1983.

12. Sutton WL: Aliphatic and alicyclic amines. In Fassett DW, Irish DD (eds): Industrial Hygiene and Toxicology, 2nd ed., Vol 2, Toxicology, p 2045. New York, Interscience, 1963.

13. Watrour RM and HN Shultz: Cyclohexylamine, p-chloronitrobenzene, and 2aminopyridine: Toxic effects in industrial use. Ind Med Surg 19:317, 1950.

14. Daniels W: Health hazard evaluation report no. 89-039, Bess Kaiser Medical Center, Portland, Oregon.

15. Hills B, Lushniak B, Sinks T: Health hazard evaluation report no. 89-057, Cincinnati Electronics Corp., Cincinnati, Ohio.

16. NIOSH (1977). Criteria for a recommended standard - occupational exposure to formaldehyde. Cincinnati, OH: U.S. Department of Health, Education, and Welfare, Public Health Service, Centers for Disease Control, National Insitute for Occupational Safety and Health, DHEW (NIOSH) Publication No. 77-126.

17. Stayner L, Smith AB, Reeve G, Blade L, Keenylside R, and Halperin W (1985). Proportionate mortality rate of workers exposed to formaldehyde. Am J Ind Med 7:229-40.

18. Blair A, Saracci R, Stewart PA, Hayes RB, and Shy C (1990). Epidemiologic evidence on the relationship between formaldehyde exposure and cancer. Scand J. Work Environ Health. 16:381-93. 
Page 11 - Health Hazard Report No. 94-0023

19. National Institute for Occupational Safety and Health. Current Intelligence Bulletin 34 - Formaldehyde: Evidence of Carcinogenicity. DHHS (NIOSH) Publication No. 81-111. April, 1981.

X. AUTHORSHIP AND ACKNOWLEDGEMENTS

Report Prepared By: $\quad$ Edward A. Kaiser, M.S., Ph.D.

Regional Industrial Hygienist

NIOSH, Region I

JFK Federal Building

Boston, Massachusetts

David C. Sylvain, M.S., CIH

Regional Industrial Hygienist

NIOSH, Region I

JFK Federal Building

Boston, Massachusetts

Originating Office: Hazard Evaluations and Technical

Assistance Branch

Division of Surveillance, Hazard

Evaluations, and Field Studies

Sample Analysis By: Measurements Research Support Branch

Division of Physical Sciences and Engineering

DataChem

960 West LeVoy Drive

Salt Lake City, Utah

XI. DISTRIBUTION AND AVAILABILITY OF REPORT

Copies of this report may be freely reproduced and are not copyrighted. Single copies of this report will be available for a period of 90 days from the date of this report from the NIOSH Publications Office, 4676 Columbia Parkway, Cincinnati, Ohio 45226. To expedite your request, include a self-addressed mailing label along with your written request. After this time, copies may be purchased from the National Technical Information Service, 5285 Port Royal Road, Springfield, VA 22161. Information regarding the NTIS stock number may be obtained from the NIOSH Publications Office at the Cincinnati Address. 
Page 12 - Health Hazard Report No. 94-0023

Copies have been sent to:

1. VA Medical Center

2. AFGE, Local 2604

For the purpose of informing affected employees, copies of this report shall be posted by the employer in a prominent place accessible to the employees for a period of 30 calendar days. 